DOI https://doi.org/10.18551/rjoas.2018-11.35

\title{
FEASIBILITY ANALYSIS OF WASTE RICE CULTIVATION (ORYZA SATIVA L.) ON OPTIMAL SUB LANDS OF WEST ACEH REGENCY, INDONESIA
}

\author{
Fuqara Fantashir Awwal* \\ Graduate Program, Syiah Kuala University, Banda Aceh, Indonesia \\ Sofyan, Hakim Lukman \\ Faculty of Agriculture, Syiah Kuala University, Banda Aceh, Indonesia \\ *E-mail: opan.pano89@gmail.com
}

\begin{abstract}
Farmers should be understand about the cost of production in order to a farmhand who run got advantage maximum. The cost of production in lowland rice farming consist of the cost of purchasing seeds, fertilizers, pesticides, insecticides, labor costs, equipment rental costs, and post-harvest costs. From the results of the analysis, if the average wetland area for each respondent is $0.9 \mathrm{Ha}$, then the amount of production costs that must be spent in the paddy cultivation cultivation for one planting season is $\mathrm{Rp}$. 2,552,000. From the results obtained, with an average land area of $0.9 \mathrm{Ha}$, the total production is $74,000 \mathrm{~kg}$. The production obtained by each respondent varies, this is due to the land area, cultivation system, and the availability of different capital. In lowland rice farming, the production produced by farmers is in the form of rice with a selling price of Rp.4,100 per kilogram. The results of this study concluded that the total income of respondents was Rp. 136,724,000, - with an average income of Rp. 3,598,000, -for each planting season of the 38 respondents who were sampled in this study. In addition to the area of land and the amount of production income from respondents is strongly influenced by the costs incurred in running rice farming on suboptimal land. The results of the analysis show that the B/C Ratio value of 1.4 is greater than zero. The value of $B / C$ Ratio determines that rice farming is feasible to cultivate. This value means that if the addition of one unit of cost is used or issued in the rice field farming, then the farm will get an additional benefit of one rupiah.
\end{abstract}

\section{KEY WORDS}

Feasibility, analysis, sub-optimal land, rice.

Food needs will continue to grow along with the increase in population, on the other hand fertile land decreases, both due to the conversion of land to the plantation sub-sector and outside the agricultural sector, so that they have to find another alternative by optimizing sub-optimal land that is still very wide and scattered throughout Indonesia.

Table 1 - Sub-Optimal Land Distribution (Data Analysis Scale 1: 250,000)

\begin{tabular}{|c|c|c|c|}
\hline \multirow{6}{*}{$\begin{array}{c}\text { Mainland Indonesia } \\
(191.09 \text { Million } \mathrm{Ha})\end{array}$} & \multirow{4}{*}{ Wetlands (46.62 million $\mathrm{Ha}$ ) } & \multirow{3}{*}{ Swamp } & $\begin{array}{c}\text { Tidal } \\
\text { (8.35 Million } \mathrm{Ha})\end{array}$ \\
\hline & & & $\begin{array}{c}\text { Low lands } \\
(11.67 \text { Million } \mathrm{Ha})\end{array}$ \\
\hline & & & Peat (14.93 million $\mathrm{Ha})$ \\
\hline & & $\begin{array}{c}\text { Non Swamp } \\
\text { (8.7 Million Ha) }\end{array}$ & - \\
\hline & \multirow[b]{2}{*}{ Dry land (144.47millionHa) } & Acid (107.36 million $\mathrm{Ha}$ ) & \multirow[b]{2}{*}{-} \\
\hline & & $\begin{array}{c}\text { LK Dry Climate } \\
\text { (10.75 Million } \mathrm{Ha})\end{array}$ & \\
\hline
\end{tabular}

Source: Agricultural Research and Development Agency Ministry of Agriculture (2013).

The Central Bureau of Statistics, Aceh Province (2014), mentions that land use in Aceh Province consists of 380,709 ha of dry land, 224,027 ha of fields, 170,362 ha of grassland 
and 732,500 ha of plantations. These lands are generally classified as sub-optimal land which has great potential to be utilized. Therefore it is necessary to inventoried and analyzed technological innovation needs so that the land can be utilized.

Sub-optimal land has great potential to be used as a strategic choice for the future development of agricultural production areas that face increasingly complex challenges, especially to compensate for the shrinking of fertile land and increase production demand, including food security and agribusiness development (Alihamsyah, 2002).

Almost all areas of Aceh cultivate rice. One of them is West Aceh Regency. This West Aceh Regency has sub-optimal land potential in the form of extensive dry land which is estimated to reach $1,300.87 \mathrm{Km} 2$ (BPS, 2015). Dominant dry sub-optimal land is in Meureubo District, West Aceh Regency and several other sub-districts with a smaller percentage. The fact that so far the land has generally not been used optimally because farmers do not master technology properly.

\section{METHODS OF RESEARCH}

Data collection method is part of the data collection instrument to determine whether or not a study is successful. Research data consists of primary data and secondary data. Primary data obtained from farmers using structured interviews guided by questionnaires. Secondary data is data obtained from agencies, related agencies, and libraries. Qualitative analysis was used to describe descriptively the description of primary data and secondary data obtained during the study. This analysis is used to describe the characteristics of respondents at the research location.

The aim of the research was to calculate the income of rice farming on sub-optimal land within a period of one production, with the formula: (Soekartawi, 1995)

$$
\mathrm{NI}=\mathrm{TR}-\mathrm{TC}
$$

Where: $\mathrm{NI}=$ Net Income; $\mathrm{TR}=$ Total Revenue; TC = Total Cost.

R/C Ratio states the feasibility of a business whether profitable, break even or a business can be said to have a loss (Firdaus, 2008). Systematically (R/C) can be formulated as follows.

$$
\text { R/C Ratio }=\text { TR TC }
$$

Where: $\mathrm{TR}=$ Total Revenue; $\mathrm{TC}=$ Total Cost.

Criteria based on $R / C$ Ratio are: $R / C$ ratio $>1$, sub-optimal cultivation of paddy fields is feasible; $R / C$ ratio $=1$, then the sub-optimal land cultivation rice cultivation business is not profitable and does not lose; $R / C$ ratio $<1$, sub-optimal cultivation of paddy field cultivation is not feasible to cultivate.

The next analysis to declare business feasibility is to calculate the BCR (Benefit Cost Ratio) with the following formula:

$$
\text { Net } B / C=B / C
$$

Where: $B C R<1$, Farming is not feasible; $B C R \geq 1$, Farming is feasible.

Break Event Point Analysis (BEP). The main point of return (Break Event Point) is a value of commercial sales at a certain period which is the same amount as the cost incurred so that the entrepreneur at that time does not suffer losses also does not get profit and to know at what level of production so that the point of return and for knowing at what acceptance so as to create the main return point (Rahardi, F, 2003). The BEP formula used is as follows:

$$
\begin{gathered}
\text { BEP Price }=\frac{T C}{Q} \\
\text { BEP Production }=\frac{T C}{P}
\end{gathered}
$$




\section{RESULTS AND DISCUSSION}

The location of this study was conducted in Meureubo District, West Aceh District, Aceh Province. The population of this study was all sub-optimal rice farmers in Meureubo District. Consisting of the villages of Arah Puerlak, Kajeung, Geudong, Tuwi Saya, Ramti, Gleng, Lancong, Kajeung, Gaseu, Leubok Beutong, and Gunong Buloh. Sampling in this study is by purposive sampling. The total sample is 38 respondents.

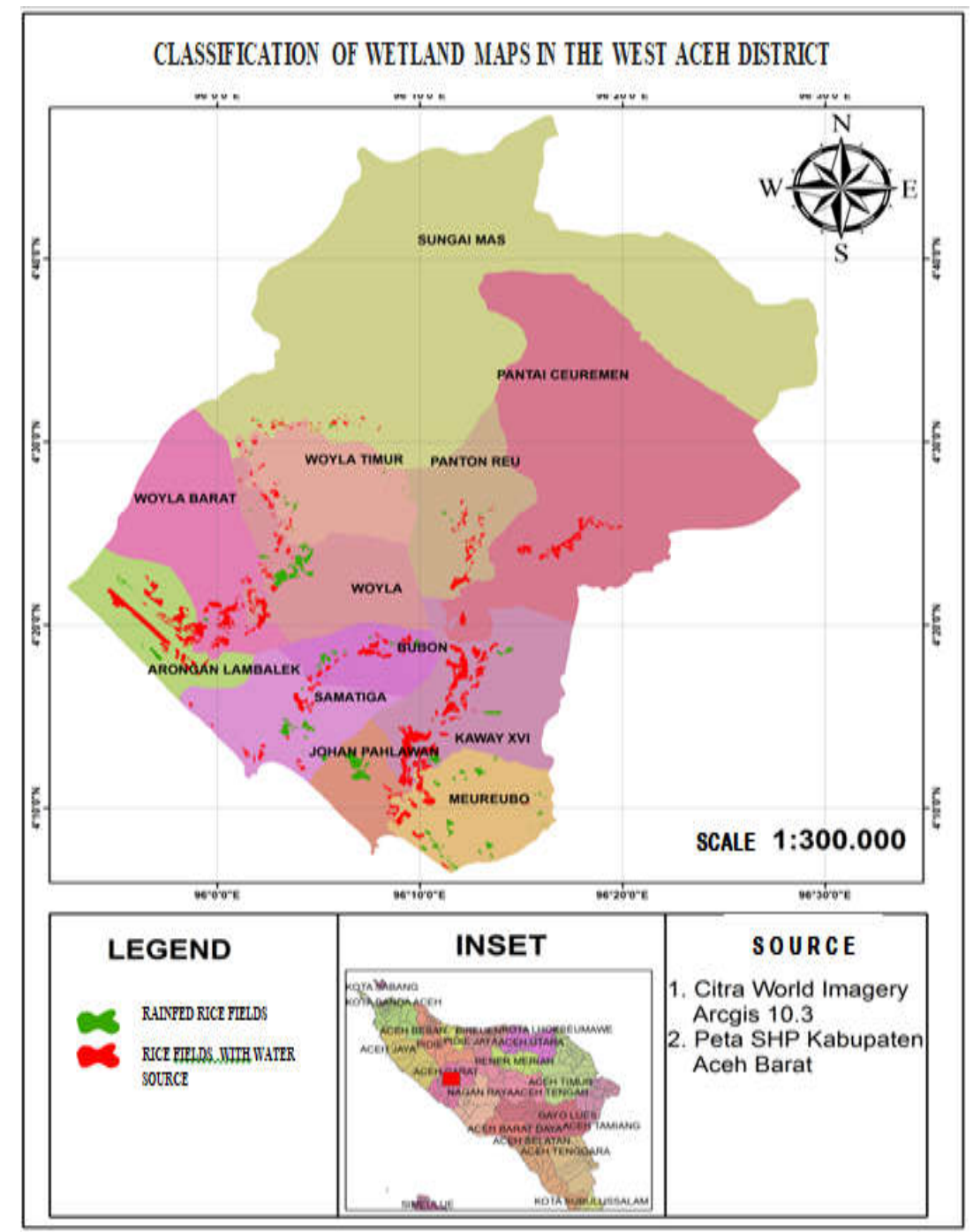

Figure 1 - Land Classification map

Analysis of Farmers' Rice Field Income in Sub-Optimal Land. Production Costs According to Sudarsono in Luntungan (2012), costs are all materials that must be borne to provide goods to be ready for use by consumers. Meanwhile, according to Kartasapoetra (1988), production costs are all expenses that must be spent by producers to obtain production factors and other supporting materials to be used so that certain planned products can be realized properly. A farmer in carrying out his farm requires production costs to support the farming activities he manages. Farmers must understand the production costs so that the farms they run get maximum benefits. Production costs in lowland rice farming consist of the cost of purchasing seeds, fertilizers, pesticides, insecticides, labor costs, equipment rental costs, and post-harvest costs. Based on table 2 above, if the average rice field area for each respondent is $0.9 \mathrm{Ha}$, then the amount of production costs that must be spent in paddy cultivation cultivation for one planting season is Rp. 2,552,000 for more details the overall cost can be seen in table 3 . 
Table 2 - Characteristics of Farmers' Respondents on Rice Fields in the Sub-Optimal Land

\begin{tabular}{|c|c|c|c|c|c|c|}
\hline No. & Name & Age & Level of Education & $\begin{array}{l}\text { Sub-Optimal Rice Farmers } \\
\text { Business Experience } \\
\text { (Years) }\end{array}$ & $\begin{array}{l}\text { Land Area } \\
(\mathrm{Ha})\end{array}$ & $\begin{array}{l}\text { Land } \\
\text { Status }\end{array}$ \\
\hline 1 & Khairan & 35 & Elementary School & 5 & 2 & Private \\
\hline 2 & Syarifuddin & 47 & Elementary School & 7 & 1.5 & Private \\
\hline 3 & Juhari & 33 & Elementary School & 4 & 1 & Rent \\
\hline 4 & Samsuddin & 36 & Middle School & 5 & 1 & Private \\
\hline 5 & Syarwani & 48 & Middle School & 4 & 0.5 & Private \\
\hline 6 & M.Sufi & 35 & Elementary School & 3 & 1 & Private \\
\hline 7 & M.Sabi & 43 & Elementary School & 6 & 0.5 & Private \\
\hline 8 & Hasan J. & 44 & Elementary School & 8 & 1 & Private \\
\hline 9 & M. Syusri & 35 & Middle School & 7 & 0.25 & Private \\
\hline 10 & Ismujal & 38 & High School & 7 & 0.25 & Private \\
\hline 11 & Nurdin & 50 & Elementary School & 12 & 1 & Private \\
\hline 12 & Samsul bahri & 47 & Elementary School & 14 & 1 & Private \\
\hline 13 & Muzakir & 35 & Middle School & 5 & 0.5 & Private \\
\hline 14 & Jauhari & 45 & Middle School & 4 & 1.5 & Private \\
\hline 15 & Usman UT & 65 & Elementary School & 5 & 2 & Private \\
\hline 16 & Rusdi & 35 & High School & 6 & 0.5 & Private \\
\hline 17 & Muslem & 28 & High School & 8 & 0.5 & Private \\
\hline 18 & Zaini & 60 & Elementary School & 12 & 0.5 & Private \\
\hline 19 & Efendi & 41 & Middle School & 10 & 1 & Rent \\
\hline 20 & Jasman & 43 & Middle School & 5 & 1.5 & Private \\
\hline 21 & Mukhtar & 55 & Elementary School & 9 & 1 & Private \\
\hline 22 & Razuan & 28 & High School & 9 & 0.5 & Private \\
\hline 23 & M.Yusuf & 25 & High School & 4 & 0.5 & Private \\
\hline 24 & Bustamam & 30 & High School & 7 & 1 & Private \\
\hline 25 & Rasyidin & 38 & Middle School & 8 & 1 & Private \\
\hline 26 & Ansari & 47 & Middle School & 9 & 0.5 & Private \\
\hline 27 & Naban & 41 & Elementary School & 10 & 2 & Private \\
\hline 28 & Jalaluddin & 50 & Elementary School & 10 & 2 & Private \\
\hline 29 & Abu kari & 40 & Elementary School & 8 & 1 & Private \\
\hline 30 & Nasrun & 35 & High School & 8 & 1 & Private \\
\hline 31 & Dini & 66 & Elementary School & 9 & 1 & Private \\
\hline 32 & Ali basyah & 50 & Elementary School & 7 & 1 & Private \\
\hline 33 & Razali & 43 & Elementary School & 9 & 0.25 & Private \\
\hline 34 & Abdul rais & 50 & Elementary School & 10 & 0.5 & Private \\
\hline 35 & Amran & 45 & Middle School & 9 & 1.5 & Private \\
\hline 36 & Amri & 43 & Elementary School & 9 & 2 & Private \\
\hline 37 & Taqwa & 50 & Elementary School & 7 & 1.5 & Private \\
\hline 38 & Syafari & 53 & Elementary School & 10 & 1 & Private \\
\hline
\end{tabular}

Source: primary data processed (2018).

Table 3 - Production Costs of Rice Farmers in the Sub-Optimal Land (Planting Season/0.9 Ha)

\begin{tabular}{llll}
\hline No. & Types of Production Costs & Total Production Costs (Rp) & Average Production Cost (Rp) \\
\hline 1. & Seed Costs & $6,574,000,-$ & $173,000,-$ \\
2. & Fertilizer Costs (Urea, SP-36, NPK) & $28,158,000,-$ & $741,000,-$ \\
3. & Cost of Pesticides & $6,840,000,-$ & $180,000,-$ \\
4. & Insecticide Costs & $4,104,000,-$ & $108,000,-$ \\
5. & TK Wage Fees & $38,000,000,-$ & $1,000,000,-$ \\
6. & Equipment Rental Fees & $3,800,000,-$ & $100,000,-$ \\
7. & Post Harvest Costs (Sacks, transportation) & $9,500,000,-$ & $250,000,-$ \\
Total & & $96,976,000,-$ & $2,552,000,-$ \\
\hline
\end{tabular}

Source: primary data processed (2018).

Production is a process of utilizing available resources, which are expected to produce results that are more than all the sacrifices that have been given (Hernanto, 1995). Farmers who carry out farming activities want high production so that they can increase income. From the results obtained, with an average land area of $0.9 \mathrm{Ha}$, the total production is $74,000 \mathrm{~kg}$. The production obtained by each respondent varies, this is due to the land area, cultivation system, and the availability of different capital. Production results obtained are less than the production on normal land. this is because sub-optimal land on dry land can reduce the amount of production. For more details can be seen in table 4 .

Acceptance is an estimate between the production obtained and the selling price (Sudiyono, 1991). Revenue is obtained from the total production multiplied by the selling price. According to Kotler (2001) in Lumintang (2013), price is the amount of money charged 
on a product or service, or the value exchanged by consumers for benefits because of owning or using the service product. In the lowland rice production farms produced by farmers are in the form of rice with a selling price of Rp. 4,100 per kilogram. For more details can be seen in table 4 .

Table 4 - Total and Average Acceptance of Rice Field Respondents in Sub-Optimal Land/Season (0.9 Ha)

\begin{tabular}{lll}
\hline Description & Total & Average \\
\hline Production & $74,100 \mathrm{Kg}$ & $1,950 \mathrm{~kg}$ \\
Acceptance & Rp. $233,700,000,-$ & Rp. $6,150,000,-$ \\
\hline
\end{tabular}

Table 3 shows that the production produced by the 38 respondents was 74,100 kilograms of rice with a total revenue of $\mathrm{Rp}$. 233,700,000 with an average of $\mathrm{Rp} .6,150,000$ per planting season. The acceptance of each farmer is different depending on the production produced and the selling price that applies when the farmer sells his produce.

According to Belkaoui (2000), said income comes from the sale of goods and services and is measured by the burden borne by the customer, client, or tenant on the goods and services delivered to them. Farming income is the difference between revenue and total costs used in carrying out farming. This is in line with the opinion of Hadisapoetra in Sudana (2013), which states that farm income is the total net income derived from all farm activities which is the difference between total revenue and total costs incurred. The results of this study concluded that the total income of respondents was Rp. 136,724,000 with an average income of Rp. 3,598,000 per planting season of the 38 respondents who were sampled in this study. In addition to the area of land and the amount of production income from respondents is strongly influenced by the costs incurred in running rice farming on suboptimal land.

Business Feasibility Analysis of Rice Fields in Sub-Optimal Land. According to Ibrahim (2009), business feasibility analysis is an activity of analyzing, reviewing, and researching to assess the extent to which benefits can be obtained in carrying out a business activity. The feasibility analysis of paddy farming business using R/C Ratio and Benefit Cost ratio (B/C Ratio). This analysis is to calculate the ratio of income and production costs.

Requirements for provisions: $B C R<1$, Farming is not feasible; $B C R \geq 1$ Farming is feasible; $R / C$ ratio $>1$, sub-optimal cultivation of paddy fields is feasible; $R / C$ ratio $=1$, then the sub-optimal land cultivation rice cultivation business is not profitable and does not lose; $\mathrm{R} / \mathrm{C}$ ratio $<1$, sub-optimal cultivation of paddy field cultivation is not feasible to cultivate.

The results of the analysis are shown in table 5 below.

Table 5 - Average and Total Revenue, Production Costs, Revenue, R/C and B/C Ratio of Sub-Optimal Rice Field Farming in Sub District of Meurebo

\begin{tabular}{lll}
\hline Description & Total & Average \\
\hline Acceptance & Rp. 233,700,000,- & Rp. 6,150,000,- \\
Production Costs & Rp. 96,976,000,-- & Rp. 2,552,000,- \\
Income & Rp. 136,724,000,- & Rp. 3,598,000,- \\
R/C & - & 2.4 \\
B/C & - & 1.4 \\
\hline
\end{tabular}

Based on the results of the calculation above, it can be seen that if the average revenue obtained by the respondent farmers in the study area amounted to Rp. amounting to Rp 3,598,000, the value of R/C Ratio is 2.4 . That is, every Rp 1 spent by farmers for the cost of farming lowland rice will generate a profit of $R p 2.4$. Because the value of $R / C$ Ratio is greater than $1(R / C>1)$, rice farming is feasible to cultivate. Thus, if farmers plant rice with an area that is getting bigger then the profits will be even greater. The results of the analysis show that the $\mathrm{B} / \mathrm{C}$ Ratio value of 1.4 is greater than zero. The value of $\mathrm{B} / \mathrm{C}$ Ratio determines that rice farming is feasible to cultivate. This value means that if the addition of one unit of cost is used or issued in the rice field farming, then the farm will get an additional benefit of one rupiah. 
However, there are some farmers who have low farm income so that the BCR value is $<1$ and categorized as not feasible. Based on the results of the study, there were 87 percent of respondents in the feasible category because of the $B C R$ value $\geq 1$, while the remaining 13 percent of respondents were in the improper category because of the BCR value $<1$. This is because production is not maximized. In addition, the low income received by respondents is also caused by spending on a substantial production cost, namely in the labor sector, on average the respondents have to incur substantial costs to rent equipment and farm laborers to manage their land. This is because most of the farmers in carrying out their farming are not supported by machines and equipment that are owned by themselves so that they have to rent which of course requires substantial additional costs.

Break Event Point Analysis (BEP). The main break point (Break Event Point) is an output level point where lowland rice farming activities do not get profit / profit and also do not experience losses.

$$
\begin{aligned}
& \text { BEP Price } \quad=\frac{T C}{Q}=\frac{2,552,000}{1,950}=1,308 \\
& \text { BEP Production }=\frac{T C}{P}=\frac{2,552,000}{4,100}=623
\end{aligned}
$$

Break Even Point on lowland rice farming in Meurebo Sub-district, West Aceh District, based on the calculation, produced a BEP Price of Rp. 1,308 and BEP Production of $623 \mathrm{~kg}$. That is, if the respondent farmers in the study area produced $623 \mathrm{~kg}$ of paddy rice production with a selling price of Rp 1,308/kg, then the rice field farming would break even, ie no loss or gain profit.

\section{CONCLUSION}

The average land area of the respondent's farm is $0.9 \mathrm{Ha}$, so the average production cost that must be spent by the farmer is Rp. 2,552,000;

The average revenue obtained by lowland rice farmers in the study area is $\mathrm{Rp}$. $6,150,000$, and the production cost is Rp. $2,552,000$, then the R/C ratio is obtained at 2.4 . then rice farming is feasible. Thus, if farmers plant rice with an area that is getting bigger then the profits will be even greater;

Break Even Point or break-even point on wetland rice farming based on calculations produces a BEP price of Rp. 1,308 and a BEP of production of $623 \mathrm{~kg}$. That is, if the respondent farmers in the study area produced $623 \mathrm{~kg}$ of paddy rice production with a selling price of Rp 1,308/kg, then the rice field farming would break even, ie no loss or gain profit.

\section{REFERENCES}

1. Badan Pusat Statistik. 2013. Luas Lahan menurut Penggunaan 1998-2002. Tahunan.

2. Belkooui. 2000. Konsep Pendapatan, dalam http dwiermayanti.wordpress.com/konseppendapatan. Diakses pada 28 September 2018.

3. Hernanto. 1988. IImu Usahatani. Jakarta: Penebar Swadaya

4. Ibrahim, Y. 2009. Studi Kelayakan Bisnis. Jakarta: Rineka Cipta

5. Kartasapoetra. 1988. Pengantar Ekonomi Produksi Pertanian. Penebar Swadaya.

6. Rahardi dan Hartono, 2000. Agribisnis Peternakan. Jakarta: Penebar Swadaya

7. Rahardi, F, 2003. Agribisnis Tanaman Buah. Jakarta: Penebar Swadaya

8. Soekartawi. 1995. Analisis Usahatani. Jakarta: Universitas Indonesia.

9. Sudiyono, A. 1991. Ekonomi Pertanian. Jakarta: Penebar Swadaya.

10. Sudana. 2013. Kelayakan Usaha Budidaya Ikan Lele Dumbo (Clarias gariepinus) dan Pengaruhnya Terhadap Tinggkat Pendapatan Petani Ikan Lele di Kabupaten Tabanan. Jurnal manajemen agribisnis. 1(1). 